\title{
Zero Waste Concept Of Strengthening And Food Safety Results Of Libuo Community Fisheries Residents Of Dungingi District Gorontalo City
}

\author{
Author \\ Sri Subekti, Wahju Tjahjaningsih, Dwi Yuli Pujiastuti, Putri Desi Wulan Sari \\ Correspondence \\ Faculty of Fisheries and Marine Universitas Airalngga Surabaya 60115. \\ dwiyp@fpk.unair.ac.id/putri.dw@fpk.unair.ac.id
}

\begin{abstract}
The potential of fishery resources in Gorontalo is quite abundant because of its strategic geographical position bordering Tomini bay. Gorontalo, especially in the Dungingi District, is one of the regions with promising potential fisheries resources where fishery application activities are not only focused on fish cultivation but also processing fishery products. However, people's understanding of fish processing that can only be obtained from their meat makes the community's income in the Libuo Village, Dungingi District Gorontalo City tend to be unstable. The Libuo community as fishery product processing actors need to be given an understanding of the potential and diversification of fishery products that can be produced from by-products that can be obtained from bones, scales, stomach contents, heads, and fish skins so that the application of zero waste can be implemented. Also, as an effort to increase public understanding related to the shelf life of fishery products which tends to be fast, the use of carrageenan as an alternative to edible coatings needs to be introduced to the community as a form of food safety of fishery products. Thus the benefits will be gained from increasing the added value of fisheries and a better level of food safety.
\end{abstract}

Keywords: zero waste, food safety, edible coating, carrageenan, Gorontalo

Received: 11 Desember 2019. Accepted: 20 Januari 2020

\section{Introduction}

Indonesia is a country with a large enough fishery land which is cultivated in both fresh and sea waters. According to data from the Ministry of Maritime Affairs and Fisheries (2018), the potential of freshwater resources used in the fisheries business is quite large consisting of public waters, ponds, rice mina, and ponds of 5,199,844 hectares. Of the total land area, 972,300 Ha has been utilized so that there is still over $3,000,000 \mathrm{Ha}$ that has the potential to be developed.

Gorontalo City is the capital of Gorontalo Province, Indonesia. Gorontalo City is the largest and most populous city in the Tomini Bay region, making Gorontalo City the center of economy and services, trade, education, and the center of the spread of Islam in Eastern Indonesia. Gorontalo City is bordered by Bone Bolango Regency in the north, Bone Bolango Regency in the east, Tomini Bay in the south and Gorontalo
Regency in the west. The total area of Gorontalo City is $79.03 \mathrm{Km} 2$ and has a population of 210,882 inhabitants. Gorontalo City consists of 9 Subdistricts, one of which is the Dungingi Subdistrict which has 5 Subdistricts, namely Libuo, Huangobotu, Tomulabutao, South Tomulabutao, and Tuladenggi. The length of the coastline ranges from $80 \mathrm{~km}$ (13.6 of the length of the coast of Gorontalo Province) has a characteristic rocky/sandy beach with an area of EEZ approximately $587.6 \mathrm{~km} 2$. Fishery production is dominated by capture fisheries and aquaculture in Lake Limboto covering \pm $3000 \mathrm{Ha}$ hectares and freshwater ponds of 580 hectares. The number of fishermen in Gorontalo City is around 3000 people.

The majority of Lingsar Subdistrict residents are fish farmers both to meet the demand for seeds and to measure the consumption of the people in West Lombok Regency. Two villages are quite advanced, namely Saribaye and Sigerongan villages. 
There are quite a lot of freshwater fish farmers in Saribaye Village, one of them is the Pade Girang Cultivation Group and for Sigerongan Village there is the Telaga Biru Fish Cultivation Group. Both groups cultivate several types of fish, namely tilapia, catfish, catfish, and goldfish. But the type of fish that is superior in cultivation is tilapia because consumer demand is quite high.

Most of the people in Libuo Village, Dungingi District, Gorontalo City are fish cultivators and processors. Cultivation carried out in freshwater waters is the cultivation of tilapia and gourami. As for the processing of fishery products, it is more related to salting and fuming fish. Byproducts from fisheries production are often considered waste and are simply thrown away. Ignorance of the potential that can still be processed from the byproducts of fisheries production is a challenge for Universities to provide further understanding to the community, especially in the Libuo Village, Dungingi District, Gorontalo City. The community's indifference to the cleanliness of processing locations or preservatives added to fishery products makes the Libuo people less aware of the importance of food security for fisheries. Understanding the processing of fishery byproducts needs to be upheld which aims to reduce waste that hurts the environment and health as well as increasing the economic value of waste generated in the processing process (Apriandi et al., 2018). Food safety is the condition and effort needed to prevent food from possible biological, chemical and other contaminants that can interfere with, harm, and endanger human health (Government Regulation, 2004)Until now there has been no effort made either by fish processing actors or related institutions to diversify byproducts of fishery products. The potential use of these by-products should receive special attention to be able to prosper the Libuo community. One effort that can be done is to provide solutions to utilize all parts of the fish's body to become food or non-food products that have added value. Besides, the Libuo's lack of awareness of the importance of food security, especially in fishery products, enables counseling and assistance through community service programs by the Faculty of Fisheries and Marine Airlangga University.

\section{Method}

The community service activities were followed by family members of the fish processing group in Libuo Village, Dungingi District, Gorontalo City. Community service activities are carried out by providing counseling to 25 fishery processors. Fishery product processing activities at the community service location are activities to strengthen the concept of zero waste and food safety of fishery products. The activity of strengthening the concept of zero waste is carried out by providing counseling on various processed products obtained from all parts of the fish so that it does not produce by-products (zero waste). One of the strengthening of the concept of zero waste is to show fishery by-products which include chitosan, fish meal, and processed diversification. An understanding of food security helps Libuo's people to become more concerned about nutrition and health in the surrounding environment. Furthermore, there will be a direct review and evaluation of community activities related to the application of zero waste that has been given and food safety by applying carrageenan as an edible coating on smoked fish. Implementation of activities using structured methods by the stages presented in Figure 1. 


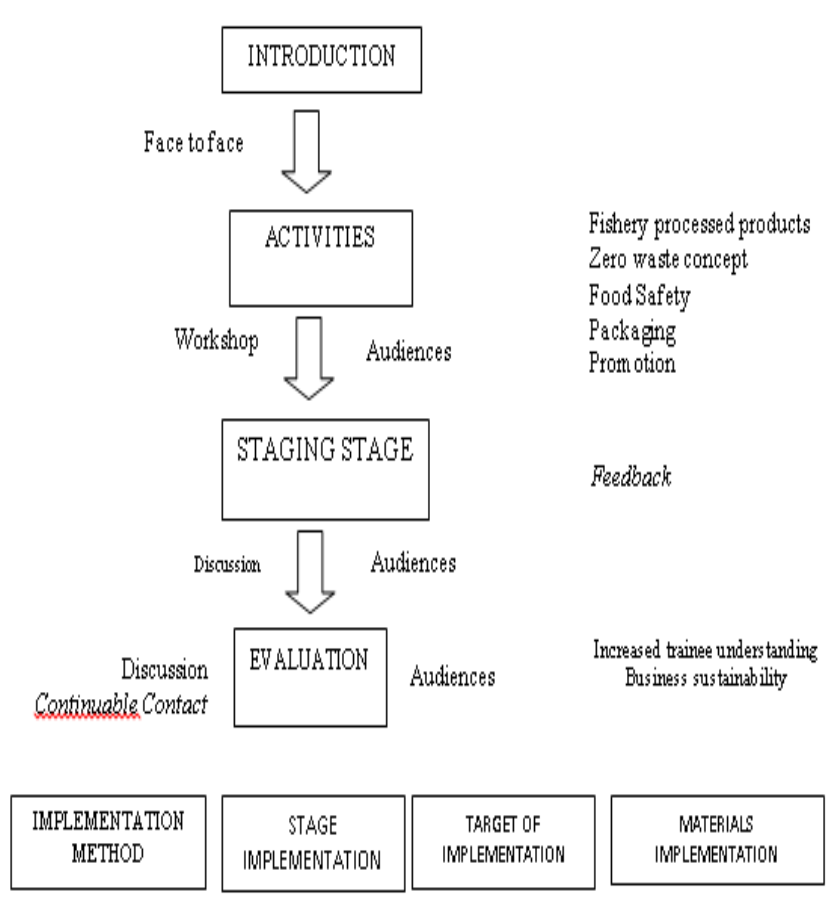

Figure 1.Method of Implementing Community Service Activities.

In the implementation of community service activities in Libuo Village, Dungingi District, Gorontalo City, the emphasis on welfare and health aspects. The Libuo community is invited to be able to know, understand and practice the concept of zero waste by diversifying fish preparations and their by-products. Besides, people are introduced to edible coatings using carrageenan as a protective product from oxidation and help extend the shelf life of processed fish products. After implementing the counseling program, a mentoring and evaluation process will be carried out to be able to measure the level of understanding of the Libuo community on the material that has been delivered and practiced by conducting discussions.

\section{Result and Discussion}

Counseling in the Community Service was conducted at the UMKM Cafugo Pisces Jalan. Belimbing PERUM Balinda Bakti Blok D No. 18 Libuo Village, Dungingi
District, Gorontalo City on August 30, 2019. The extension activity was attended by approximately 25 participants consisting of Gorontalo city fisheries instructors, heads and members of the fish processing group around Libuo Village, Dungingi District, Gorontalo City. The material given to the participants of the extension was the diversification of processed fishery products resulting from the utilization of all parts of the fish's body as a reinforcement of the concept of zero waste, the application of sanitation and hygiene and the processing of fish with fermentation. Determination of the material is based on discussions that have been conducted that some fisheries processing communities still have not applied proper sanitation standards so that it can affect processing, making products have a shelf life and low food safety.

The counseling activity was started by delivering the activity objectives about the importance of the application of sanitation and hygiene in the processing of fishery products. Not only processing but processes ranging from received raw materials to packaged and marketed need to be a concern for all participants who undergo the fisheries product processing sector. Fishery raw materials, known as perishable food, can be adjusted according to standards such as when raw materials come from the processing agent, it must be ensured that the fish are in fresh condition by always keeping the body temperature of the fish cold using cured ice. Furthermore, in terms of processing, facilities and infrastructure must also be considered. The cleanliness of the production floor, the layout of the production, the means of production, the water used must also be considered so that it is always washed when in contact with fish or products. Then the cleanliness of workers also has an impact related to the length of the shelf life of fishery products. Workers must also wear masks, hair must be tied, wear gloves and wash 
hands before and after the production process. This will minimize contaminants that can reduce the shelf life of the product and prevent workers from things that can be dangerous so that sanitation and hygiene are needed not only as a product safety but also security for workers. In the counseling, the fisheries processing sector actors were given information about 6 steps to wash hands properly. Previously when the participants were asked about how to wash their hands properly they did not know the steps to wash their hands so they were given a demo of washing hands properly with 6 steps, namely: 1. Start washing your hands with clean running water, then use enough hand washing soap into your palms.

2. Glue between right hand and left hand.

3. After that, position your right palm above the back of your left hand and vice versa.

4. The palm with the palm and between the fingers must also be cleaned with soap. Rub the soap between your fingers until it foamy. 5. Place the backs of fingers on the other palm with fingers interlocking, so that they are more evenly distributed to all parts of the hand.

6. The right thumb is rubbed around by the left palm and vice versa.

7. The left finger closes, rubs turning right and left on the palm and vice versa.

Fishery products are mostly used by the people of Gorontalo, only the meat, but the by-products in the form of scales, skin, head, bones and stomach contents have not been used optimally. Understanding the concept of zero waste will add information to the community that the use of fishery products can be used from the whole body of fish so that it does not produce waste and increase the diversification of processed fishery products. Fish can be processed traditionally and modernly. Some traditional forms of processed fisheries are fermentation, drying, salting, fumigating, whereas modern forms of processed fisheries can be frozen and canning.

Smoked fish is a traditional fish processing product using smoke obtained from the burning of wood, coconut shells or the use of liquid smoke. Smoked fish is known as a product that has a low shelf life of 2-3 days. This smoked fish is a mainstay of fish processing agents in Gorontalo City so that the solution to extend the shelf life is a concern for the community service team. The solution offered is the use of carrageenan as an edible coating or coating for smoked fish. The edible coating is one layer that is proven to inhibit oxidation. So that edible coating can prevent the decline in quality and can extend shelf life. Edible coating components are grouped into three, namely hydrocolloids, lipids, and composites. Hydrocolloids used in making edible coatings in the form of proteins or polysaccharides. Polysaccharides are cellulose and its derivatives, starches and their derivatives, pectin, sea algae extract (alginate, carrageenan, agar), gum (gum arabic and karaya gum), xanthan, chitosan, and others. So that the addition of carrageenan can increase the shelf life of smoked fish. Also, merging methods are needed such as smoked fish kept at a low temperature in a cooler and closed packaging which is recommended to use vacuum packaging to minimize contact with air and microorganisms that are expected to extend its shelf life.

Furthermore, also introduced the fermentation method in processing fishery products. Fermentation itself is the process of breaking down complex compounds into simpler compounds using the help of microorganisms and enzymes under controlled conditions. Sea fish that are often found and marketed by the Gorontalo city community in the fresh form do not have much added value and produce fishery waste. One of the fishery waste that can still be utilized is the entrails of fish. The entrails of 
fish can be used as bakasang products by using a fermentation process. The stages of the process are:

1. Separate offal (intestine, stomach, liver, heart, lungs, eggs) from skipjack fish, cut into small pieces, then wash and drain

2. Add lime and then salt $25 \%$ of the weight of the innards

3. Put in a bottle and dried for 10 days

In addition to the contents of the stomach, meat from fish can be used as raw materials for fermentation of scars. The process of making these scars is almost the same as the process of making fish, only in the process of making scars there is the addition of carbohydrates. Bekasam is included in fermented products that use high salt content. Making scars in principle there are three stages, namely the salting process, the addition of carbohydrates and followed by fermentation. The stages of the process of making fish scavengers are as follows:

1. Weed the fish, remove the gills, the contents of the stomach and scales and then wash thoroughly in running water.

2. Fish that have been washed and drained and then covered with $15 \%-20 \%$ salt.

3. Salt-coated fish are arranged into jars / containers / pots, then each layer is sprinkled with rice until the last layer.

4. Cover the jar / container / pot then ferment for one week.

After the counseling and practice activities were carried out, the community service team held a question and answer session from the counseling participants regarding the two activities that had been carried out, namely the application of carrageenan as edible coating and fermentation. The participants were very enthusiastic about the introduction of edible coatings and fermented fermented products and some asked about the shelf life of smoked fish products when using edible coatings and where to obtain the carrageenan.
In addition, the characteristics of good marks like what. The question was answered by the team that the shelf life of fish given carrageenan coating can last a maximum of 1 week at room temperature. Therefore, the incorporation of the method of stimulation is highly recommended to be able to extend its shelf life. Carrageenan can be obtained at a chemical store with the price of $1 \mathrm{~kg}$ is 297,000 . But it should be noted in making carrageenan we only add $1 \%$ of the raw material of fish, so it is very economical. Associated with the characteristics of good scars are not visually overgrown by microorganisms such as fungi, then the rice will tend to change color to brown due to the fermentation process and as a sign that the fish is ready to be fried as a further process. In addition, there were some inputs from the participants who said that Gorontalo is famous for its three endemic fishes, namely Nike, Tuna and Tilapia. In the future, we hope that information can be provided regarding any processed product that can be processed from abundant raw materials in the Gorontalo city.

\section{Conclusion}

Community service that has been done to fishery product processors in Libuo Village, Dungingi Subdistrict, Gorontalo City has received high enthusiasm shown by high enthusiasm and motivation to participate in counseling activities. The fisheries processors synergize with the community service team of the Faculty of Fisheries and Marine Airlangga University in strengthening the concept of zero waste and food safety of fishery products by applying edible coatings as coating for smoked fish and making scars. 


\section{Suggestion}

There are three endemic fish that are abundant in the city of Gorontalo, namely Nike fish, Tuna and Tilapia which will be identified in the future Nike fish from the genus and species. In addition, tilapia fish like Tilapia has also started to become a concern for Gorontalo people so it is necessary to diversify Tilapia fish processing such as making nuggets, brains, tilapia noodles or other processed fishery products so that it can add information on processed fish for the fisheries processing community. in the city of Gorontalo.

\section{References}

Apriandi, A., Putri, R. M. S dan Suhandana, M. (2018). Penguatan Sistem Manajemen Mutu dan Konsep zero waste production pada Kelompok
Pengolah Produk Perikanan di Kampung Madung. JurnalPengabdian Kepada Masyarakat Maritim 1(1):1527.

https://www.gorontalokota.go.id/page/profil -kota-gorontalo

Kementerian Kelautan dan Perikanan. (2018). Data Statistik Kementerian Kelautan dan Perikanan. Kementerian Kelautan dan Perikanan Indonesia. Jakarta.

Peraturan Pemerintah Nomor 28 Tahun 2004 tentang Keamanan, Mutu dan Gizi Pangan

Suparmi, Slamet N. A., Ira, S. (2015). Pengaruh Edible Coating dari Karagenan terhadap Mutu Ikan Kembung Segar Selama Penyimpanan Suhu Dingin. 